Balance of Payments, Exchange Rates, and Competitiveness in Transition Economies 


\section{Balance of Payments, Exchange Rates, and Competitiveness in Transition Economies}

edited by

Mario I. Blejer

Marko Škreb

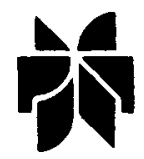

Kluwer Academic Publishers

Boston/Dordrecht/London 


\section{Distributors for North, Central and South America:}

Kluwer Academic Publishers

101 Philip Drive

Assinippi Park

Norwell, Massachusetts 02061 USA

Telephone (781) 871-6600

Fax (781) 871-6528

E-Mail<kluwer@wkap.com>

\section{Distributors for all other countries:}

Kluwer Academic Publishers Group

Distribution Centre

Post Office Box 322

3300 AH Dordrecht, THE NETHERLANDS

Telephone 31786392392

Fax 31786546474

E-Mail <services@wkap.nl>

\section{Library of Congress Cataloging-in-Publication Data}

Balance of payments, exchange rates, and competitiveness in transition economies / Mario I. Blejer and Marko Skreb (Eds.).

p. $\mathrm{cm}$.

Includes bibliographical references ( $p, \quad$ ) and index.

ISBN 0-7923-8422-9

1. Monetary policy-Europe, Eastern. 2. Economic stabilization-Europe, Eastern. 3. Balance of payments-Europe, Eastern.

4. Foreign exchange rates-Government policy-Europe, Eastern.

5. Competition, International. I. Blejer, Mario I. II. Skreb, Marko, $1957-$

HG930.7 .B35 1999

332.4'94-dc21 99-26147

Copyright (C) 1999 by Kluwer Academic Publishers

All rights reserved. No part of this publication may be reproduced, stored in a retrieval system or transmitted in any form or by any means, mechanical, photocopying, recording, or otherwise, without the prior written permission of the publisher, Kluwer Academic Publishers, 101 Philip Drive, Assinippi Park, Norwell, Massachusetts 02061.

Printed on acid-free paper.

Printed in the United States of America 


\section{Contents}

1

Transition and the Open Economy: An Overview

Mario I. Blejer and Marko Śkreb

I

Exchange-Rate Policies and the Balance of Payments

2

Current-Account Sustainability in Transition Economies

Nouriel Roubini and Paul Wachtel

3

Exchange-Rate Arrangements in the Transition Economies

Robert A. Mundell

4

Toward Virtual Exchange-Rate Stability in Western and Eastern Europe with the Advent of EMU

Ronald I. McKinnon

5

A Model of Real Exchange-Rate Determination in Transition Economies Clemens Grafe and Charles Wyplosz

6

Financing the Transition to a Market Economy: External Borrowing in the Baltics and CIS Region

John Odling-Smee and Basil Zavoico

7

Capital Flows and Stability of Financial Systems in Emerging Countries André lcard 
II

Transition and international Trade

8

Geographic Diversification of Trade in Transition Economies

Oleh Havrylyshyn and Hassan Al-Atrash

9

The Fiscal Implications of Trade Liberalization in Transition Countries

239

Vito Tanzi, Adrienne Cheasty, and Kristina Kostial

10

What Is Special About Endogenous International Trade Policy in Transition Economies?

Arye L. Hillman and Heinrich Ursprung

III

Selected Country Experiences

11

External Deficit, Exchange Rate, and Competitiveness in Croatia:

Is There a Problem?

285

Boris Vujcić and Tomislav Presečan

12

Exchange-Rate Policy in the Czech Republic: The Perils of Sticking to Fixed Exchange Rates

Fabrizio Coricelli

13

Trade, Trade Policy, and Foreign-Exchange Regimes Under Transition:

Russia and the Dutch Disease

Gur Oter and Vladimir Drebentsov

14

Balance of Payments, Exchange Rates, and Competitiveness:

Lessons for Transition Economies from the Israeli Experience

403

Jackob A. Frenkel

15

Balance of Payments, Exchange Rates, and Competitiveness in Hungary Laszló Halpern and Judit Neményi

16

Current-Account Surplus and Falling Competitiveness in Slovenia

Velimir Bole

Index 
Balance of Payments, Exchange Rates, and Competitiveness in Transition Economies 